DOI:10.17951/h.2020.54.3.7-17

\begin{tabular}{lcc}
\hline & A N N A L E S \\
UNIVERSITATIS MARIAE CURIE-SKŁODOWSKA & LUBLIN - POLONIA \\
VOL. LIV, 3 & SECTIOH H \\
\hline
\end{tabular}

\author{
BARBARA FURA \\ bfura@ur.edu.pl \\ University of Rzeszów. Institute of Economics and Finance \\ 2 Ćwiklińskiej St., 35-601 Rzeszów, Poland \\ ORCID ID: https://orcid.org/0000-0002-9601-6634
}

FLAVIA ALEX BONGA

flv.ndb@gmail.com

University of Łódź. Faculty of Management

22/26 Matejki St., 90-237 Łódź, Poland

ORCID ID: https://orcid.org/0000-0002-9574-3354

\title{
Differentiation of Companies' Environmental Initiatives in the Light of the Research Results
}

Keywords: environmental initiatives; company; environmental protection; competitiveness

JEL: O44; Q55

How to quote this paper: Fura, B. \& Bonga, F.A. (2020). Differentiation of Companies' Environmental Initiatives in the Light of the Research Results. Annales Universitatis Mariae Curie-Sktodowska, sectio H-Oeconomia, Vol. 54, No. 3.

\footnotetext{
Abstract

Theoretical background: The deteriorating condition of the natural environment, as a result of human activity, is one of the global problems that contemporary business entities must face. Companies in their attempts to comply with principles of environmental protection undertake activities aimed at better utilization of resources, production materials or improved efficiency. Such endeavours include the elimination of pollution, recycling of materials, reduction of waste generated, reduction of fuels and energy consumption, and limiting water usage. This contributes to improving corporate economic performance, thus, making production more efficient, more economical and safer.
} 
Purpose of the article: The purpose of this article is to identify the company's behavior with regard to environmental protection issues. The study tests the research hypothesis that the companies' characteristics (i.e. company size, type of activity - production/non-production, the scale of activity - local and regional, national, international) are factors that significantly differentiate the involvement of companies in activities for the environmental protection.

Research methods: The empirical analysis is based on primary data from 68 companies. It was carried out using the Mann-Whitney U test, chi-square independence test, and the correspondence analysis. The strength of the examined relationships was expressed by the V-Cramer coefficient.

Main findings: The research showed that the level of implementation of environmental initiatives depended on both the type of business activity and the size of the company. In the opinion of the surveyed entities, the implementation of pro-environmental activities aims at improving the company's image and, to a lesser extent, at obtaining specific economic benefits. Large companies were often involved in the implementation of pro-environmental activities more than small and medium-sized entities. Production entities were more involved in it, compared to non-production companies.

\section{Introduction}

Modern companies carry out activities aimed at continuous improvement of processes performed by them, so they can have a minimum negative impact on the natural environment (Zutshi \& Creed, 2015). The companies' activities focus on developing more ecological, sustainable processes and products, whose implementation is to contribute to the reduction of the use of natural resources, reduction of pollution emissions and the reduction of the amount of waste generated (O'Conor $\&$ Keil, 2017). These activities improve environmental performance, which in most companies is reflected in the improvement of the economic performance as well as increased competitiveness ( $\mathrm{Li}$, Wang, $\mathrm{Su}, \& \mathrm{Su}, 2019$ ).

Changes in the approach of business entities to the issue of environmental protection are elements of wider socio-economic changes implemented under the idea of sustainable development, circular economy, green economy or the concept of corporate social responsibility (CSR). These concepts are not new, on the contrary, since around the 1980s, they have been widely discussed both among scientists and business practitioners. Common features of these concepts are efficiency, economy, rationality and ethics. These concepts can be considered as not contradictory but interdependent (Olejniczak, 2014).

The purpose of this article is to identify the company's behavior with regard to environmental protection issues. The study verifies the research hypothesis that the companies' characteristics (i.e. size of the company, type of activity - production/ non-production, the scale of activity - local and regional, national, international) are factors that significantly differentiate the involvement of companies in activities for environmental protection. The study also contributes to the discussion on the effectiveness of voluntary pro-environmental activities of companies. 


\section{Environmental initiatives - definition and classification}

In this study, the concept of environmental initiatives is applied synonymously with the concepts of pro-environmental activities or actions for environmental protection. This approach justifies the review of the literature in which the terms are used interchangeably (e.g. Bugdol, Puciato, \& Borys, 2019; Hadryjańska, 2015; Koszarek-Cyra, 2016; Seroka-Stolka, 2016). In global terms, environmental initiatives are implemented in the areas of climate change, biodiversity protection, use of resources and waste storage as well as spreading knowledge about the situation of the natural environment. Through environmental initiatives at the micro-level, Wassmer, Cueto, and Switzer (2014) understand activities aimed at reducing the negative impact on the natural environment in the areas of energy efficiency, pollution prevention, reduction of waste generated, use of clean energy, use of environmental management systems and offering green products and services.

A more general definition of environmental initiatives provide Jacobs, Singhal, and Subramanian (2010), who understand this term as particular companies' philanthropic donations for environmental protection, commitments for voluntary emission reduction and obtaining an environmental management system certificate for compliance with the requirements of ISO 14001 standard (Jacobs et al., 2010). According to Adamczyk (2014), the area of environmental protection, as part of CSR, includes the following issues: prevention of environmental pollution, reduction of raw materials and energy consumption, and reduction of climate change. Eryigit and Özcüre argue (2015) that it includes prevention of environmental pollution, reduction of raw materials and energy consumption, and reduction of climate change.

The scope of companies' pro-environmental activities is extensive and covers the following categories (UMWŚ, 2009): waste management and resource-saving, protection of air, climate and energy conservation, sewage management, water and soil protection, noise protection, vibrations, R\&D activities, and other environmental protection activities. In this article, by environmental initiatives we mean voluntary actions by companies, by means of which companies can reduce their negative impact on the environment and thus improve it.

In production companies, the main actions for environmental protection are (Sen, Roy, \& Pal, 2015): a) reduction of air emissions, b) implementation of environmentally-friendly production processes, c) reduction of energy consumption, d) reduction of raw material consumption, e) reduction of water consumption and f) reduction of waste. They are components of production processes and have an impact on the natural environment at the time of pollution. In non-production companies, pro-environmental activities and initiatives mainly stand out (Sen et al., 2015): a) residual/waste/surplus material, b) customer satisfaction survey, c) environmental audit of suppliers, d) use of ecological transport, e) using "green" packaging, or f) concern about appropriate relations with the local community. In the case of manufacturing companies, environmental initiatives have a preventive 
or control character, however, in the case of service entities, they are not directly linked to the production process.

The main motives for introducing environmental initiatives can be divided into two categories: external and internal motives. External motives include various types of stimuli from the proximal and distal company environment that may affect decisions in environmental issues in various ways. These include the effective environmental policy, regulations on emissions trading, customer requirements or market requirements. For the internal motives, they include initial requirements and individual characteristics of the companies, such as human resources management, corporate governance, or technological trajectory (Liao, 2018).

The benefits reported by business owners, which relate to the introduction of broadly defined environmental initiatives, mainly concern (Kożuch, 2012): reduction of material consumption per unit of product, reduction of energy consumption in manufacturing processes, reduction of soil, water, air pollution, reduction of carbon dioxide emissions, reduction of noise level, use in processes production of environmentally-friendly materials, as well as reuse of waste, water, raw materials, etc. It is important to obtain image benefits, which in the long run can boost an increase in sales, profit and result in improved competitiveness.

Despite the extensive company activity regarding the implementation of environmental initiatives, the common feature of these activities is, however, uncertain as to their effectiveness, efficiency or even legality about other elements of environmental policies with proven beneficial economic, environmental and social effects (Paton, 2000).

\section{Research methods}

In the study, the source of empirical data was a questionnaire survey conducted with the representatives of companies (proxies for management systems, board members, owners/co-owners) in the fourth quarter of 2017. The study covered 68 companies from the Podkarpackie, Małopolskie, and Lubelskie voivodeships ${ }^{1}$. The degree of the company's involvement was expressed based on the subjective assessment of companies using a 5-point Likert scale.

The non-parametric Mann-Whitney U test, chi-square test, and multidimensional correspondence analysis were used for the analysis. The Mann-Whitney U test examined the differences in benefits compared to selected business characteristics, while the chi-square test of independence tested relationships between company

\footnotetext{
1 The research survey was carried out by members of the Section of Economic Applied Mathematics operating within the "Business Leaders" Science Club of the Faculty of Economics of the University of Rzeszów.
} 
characteristics and environmental initiatives. The strength of relationships between the variables was expressed by the $\mathrm{V}$-Cramer coefficient. The correspondence analysis clarified the relationships detected by the chi-square test.

\section{Results}

Small and medium-sized enterprises (SMEs), including micro companies (up to 250 employees), constituted $79.4 \%$ of the research sample, the remaining $20.4 \%$ were large companies. Among the surveyed companies, $45.6 \%$ are entities, which indicated production as the dominant type of their activity, the remaining $54.5 \%$ are non-productive entities. Those operating on a local and regional scale constitute $27.9 \%, 29.5 \%$ operate nationally and $42.6 \%$ - internationally.

This study assesses the degree of companies involved in both initiatives directly related to implemented processes, i.e. reduction of the consumption of raw materials and other materials, reduction of the amount of generated waste, saving of water and energy, minimizing the negative impact of activities on the environment and in initiatives indirectly related to production, i.e. activities to protect the environment in the locality, cooperation with other entities in support of taking measures to protect the natural environment, commitment to raising awareness on environmental issues and being responsible for the state of the environment, efforts to optimize transport. The degree of involvement of the surveyed companies in the mentioned initiatives is presented in Figure 1 and 2.

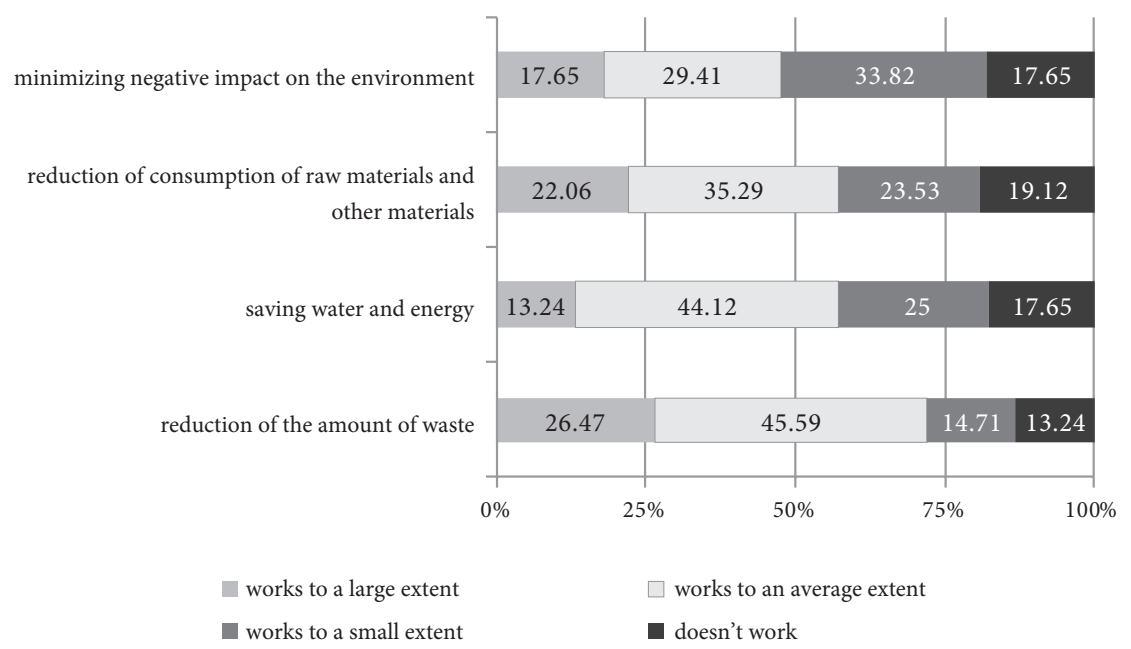

Figure 1. The companies' involvement in environmental initiatives directly related to the production process 
In the first group of initiatives, to the greatest extent, the surveyed companies were mostly involved in the reduction of waste, over $26 \%$ to a large extent and almost $46 \%$ to an average extent. The remaining $28 \%$ declared little or no involvement. A relatively similar involvement of companies was observed in saving water and energy as well as in reducing the consumption of raw materials and other materials. Approximately $57 \%$ of companies were involved, to a large and average extent, in both initiatives. To the smallest extent, the studied entities acted to reduce the negative impact of their activities on the environment in general. Only less than $50 \%$ of the respondents declared that they work to reduce the impact on the environment to a large and average extent, at the same time, over $50 \%$ of the respondents acted only to a small extent (33.82\%) or did not undertake such activity in general (17.65\%). This result may be related to the fact that almost $70 \%$ of companies (Figure 2) did not see the need to engage in activities related to expanding knowledge about the importance of environmental issues both in their company and in their environment. According to interviews conducted in companies, some of the companies (mostly non-productive entities and/or small entities) believed that due to their negligible impact on the environment, they did not have to be involved in its protection. In addition, a significant proportion of respondents complained about the lack of financial resources or the lack of time for such activities.

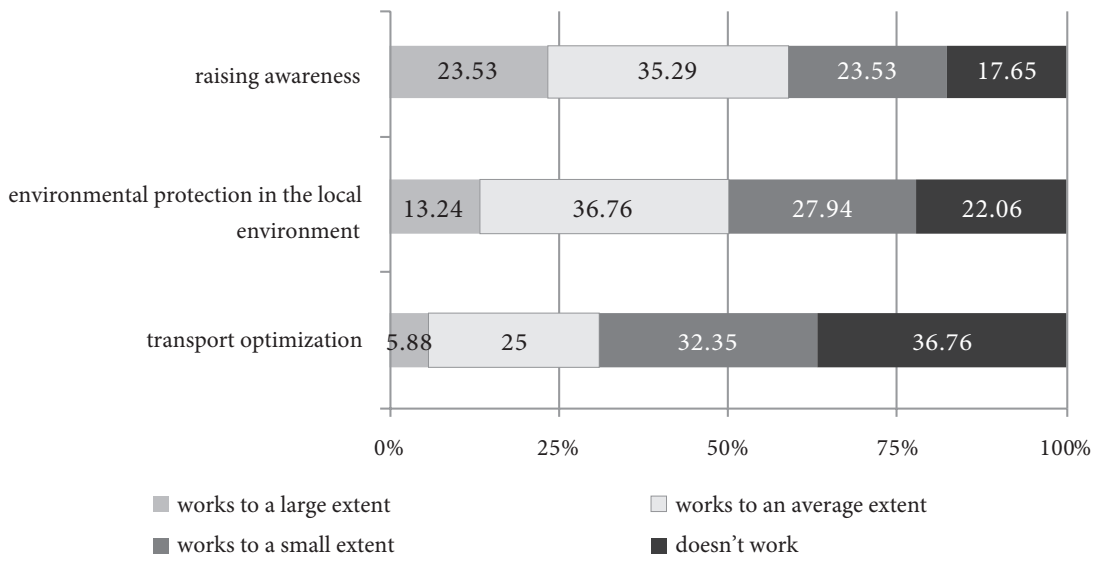

Figure 2. The companies' involvement in environmental initiatives indirectly related to the production process

Source: Authors' own study.

Most companies confirmed that they pay relatively high attention to the amount of fuel consumption by their vehicles and, if possible, choose the cheaper fuels. $50 \%$ of the companies confirmed that they purchase environmentally-friendly products. The results of the assessment of potential benefits, resulting from the company's involvement and implementation initiatives, are expressed on a scale of 0 to 5 ( 0 no benefit, 5 - very high benefit), are summarized in Table 1 . 
Pobrane z czasopisma Annales H - Oeconomia http://oeconomia.annales.umcs.pl Data: 26/04/2023 14:29:56

DIFFERENTIATION OF COMPANIES’ ENVIRONMENTAL INITIATIVES...

Table 1. Assessment of benefits resulting from the implementation of environmental initiatives

\begin{tabular}{|l|c|c|c|}
\hline Benefit & $\mathrm{N}$ & Average & Median \\
\hline Legal compliance and other requirements & 67 & 3.72 & 4.0 \\
\hline Company's image improvement & 67 & 3.46 & 4.0 \\
\hline Positive perception by local communities & 68 & 3.46 & 4.0 \\
\hline Suppliers, customers relationships improvement & 67 & 3.36 & 4.0 \\
\hline Increasing the company's competitiveness & 68 & 3.35 & 4.0 \\
\hline Increasing the number of customers & 68 & 3.34 & 4.0 \\
\hline Positive perception by the local authorities & 68 & 3.32 & 4.0 \\
\hline Improving efficiency & 68 & 3.29 & 4.0 \\
\hline Increased management/employee satisfaction & 68 & 2.84 & 3.0 \\
\hline Entering new markets & 66 & 2.82 & 3.0 \\
\hline Reduction of environmental protection costs & 68 & 2.71 & 3.0 \\
\hline Reduction of production costs & 66 & 2.61 & 3.0 \\
\hline
\end{tabular}

Source: Authors' own study.

The greatest benefit of implementing environmental initiatives is legal compliance and other requirements with an average rating of 3.72. The improvement of the company's image and the positive perception of the company by local communities obtained a rating of 3.46. Slightly lower assessment of companies obtained another image-related benefit in the form of positive perception of the company by local authorities of 3.32. To a lesser extent, as a result of involvement in pro-environmental activities, companies would improve the relationship between inputs and outputs, i.e. increase in efficiency and productivity (3.29). 50\% of companies assessed the potential benefits to be large or very large (rating 4.0 or 5.0 ), the other $50 \%$ of companies assigned a rank of 4.0 or lower.

Also, increasing the satisfaction of management/employees and entering new markets were considered as potential benefits. These benefits are obtained respectively to the average benefits of 2.84 and 2.82 . The surveyed companies slightly associated their involvement in pro-environmental initiatives with a drastic reduction in environmental protection costs (2.71), i.e. economic and social costs undertaken to implement environmental protection projects or with the possibility of reducing production costs (2.61). With the last four benefits listed in Table 1, 50\% of companies rated 3.0 or higher, and the other half assigned a rank of 3.0 or lower. The study subjected to the differentiated assessment of potential benefits by the type of economic activity (Table 2 ).

Table 2. Mann-Whitney $U$ test regarding the type of company activity

\begin{tabular}{|l|c|c|c|c|c|}
\hline Variable/Benefit & $\begin{array}{c}\text { Total ranks: } \\
\text { Group 1 }\end{array}$ & $\begin{array}{c}\text { Total ranks: } \\
\text { Group 2 }\end{array}$ & $\mathrm{U}$ & Z corr. & $\mathrm{p}$ \\
\hline Reduction of production costs & 1032.5 & 1178.5 & 402.5 & -1.8328 & 0.0668 \\
\hline Reduction of environmental protection costs & 1123.0 & 1223.0 & 420.0 & -1.9304 & 0.0536 \\
\hline Image improvement & 1049.0 & 1229.0 & 346.0 & -2.7198 & $0.0065^{*}$ \\
\hline Increasing the number of customers & 1234.5 & 1111.5 & 531.5 & -0.5280 & 0.5975 \\
\hline
\end{tabular}


Pobrane z czasopisma Annales H - Oeconomia http://oeconomia.annales.umcs.pl Data: 26/04/2023 14:29:56

\begin{tabular}{|l|c|c|c|c|c|}
\hline Variable/Benefit & $\begin{array}{c}\text { Total ranks: } \\
\text { Group 1 }\end{array}$ & $\begin{array}{c}\text { Total ranks: } \\
\text { Group 2 }\end{array}$ & $\mathrm{U}$ & $\mathrm{Z}$ corr. & $\mathrm{p}$ \\
\hline $\begin{array}{l}\text { Improving relationships with suppliers, } \\
\text { customers }\end{array}$ & 1276.5 & 1001.5 & 536.5 & 0.2340 & 0.8150 \\
\hline Compliance with requirements & 1168.0 & 1110.0 & 465.0 & -1.1805 & 0.2378 \\
\hline Entering new markets & 939.5 & 1271.5 & 309.5 & -3.0355 & $0.0024^{*}$ \\
\hline Improving efficiency & 1158.0 & 1188.0 & 455.0 & -1.4959 & 0.1347 \\
\hline Increased satisfaction & 1238.5 & 1107.5 & 535.5 & -0.4786 & 0.6322 \\
\hline Increase of competitiveness & 1192.0 & 1154.0 & 489.0 & -1.0868 & 0.2771 \\
\hline Positive perception by local authorities & 1048.0 & 1298.0 & 345.0 & -2.8980 & $0.0038^{*}$ \\
\hline Positive perception by local communities & 1223.0 & 1123.0 & 520.0 & -0.6709 & 0.5023 \\
\hline
\end{tabular}

Group 1 - non-production companies, Group 2 - production companies, $\mathrm{U}$ - result of the Mann-Whitney U test, Z corr. $-\mathrm{Z}$ statistics with continuity correction, $\mathrm{p}$ - test probability level, * significant results at $\mathrm{p}<0.05$.

Source: Authors' own study.

The type of companies' activity differentiated the assessment of possible benefits to be obtained from implementing pro-environmental initiatives. From the perspective of companies' assessment, larger image benefits and economic benefits can be expected from production companies. This is because, in the opinion of the respondents, production entities have a greater impact on the environment than non-production entities. Moreover, in the opinion of companies, limiting the negative impact on the environment may, in the case of production companies, be associated, to a greater extent, with the improvement of the company's image or the improvement of relations with local authorities.

The scale and scope of environmental initiatives implemented in companies are varied. The characteristics of companies are significant, e.g. the size of companies, which largely determines the number of resources at the disposal of companies and the number of resources allocated to environmental protection. A summary of companies' responses regarding the level of involvement in environmental initiatives by the size and type of activity is presented in Table 3 .

Table 3. Contingency table

\begin{tabular}{|c|c|c|c|c|c|c|c|}
\hline Production & Not involved & Involved & Total in a row & Size & Not involved & Involved & Total in a row \\
\hline No & 28 & 9 & 37 & S \& M & 38 & 16 & 54 \\
\hline Yes & 13 & 18 & 31 & L & 3 & 11 & 14 \\
\hline Total & 41 & 27 & 68 & Total & 41 & 27 & 68 \\
\hline
\end{tabular}

Source: Authors' own study.

The sufficient numbers in individual rows of Table 3 enabled the use of the chisquare independence test (Table 4). 
Pobrane z czasopisma Annales H - Oeconomia http://oeconomia.annales.umcs.pl Data: 26/04/2023 14:29:56

DIFFERENTIATION OF COMPANIES' ENVIRONMENTAL INITIATIVES..

Table 4. Chi-square test results

\begin{tabular}{|l|c|c|c|c|}
\hline Variable & Chi $^{2}$ Pearson & df & p & V-Cramer \\
\hline Size (S\&M/L) & 11.1235 & 1 & $0.0009^{*}$ & 0.3749 \\
\hline Production (yes/no) & 8.0208 & 1 & $0.0046^{*}$ & 0.3248 \\
\hline
\end{tabular}

$* 0.05$ level

Source: Authors' own study.

The test results showed statistically significant relationships between the company involvement in pro-environmental activities and the size of the company as well as between the involvement and the type of economic activity taking place (production/ non-production). The strength of detected relationships was average and amounted to 0.37 and 0.32 , respectively. Their clarification is the result of multidimensional correspondence analysis (Figure 3).

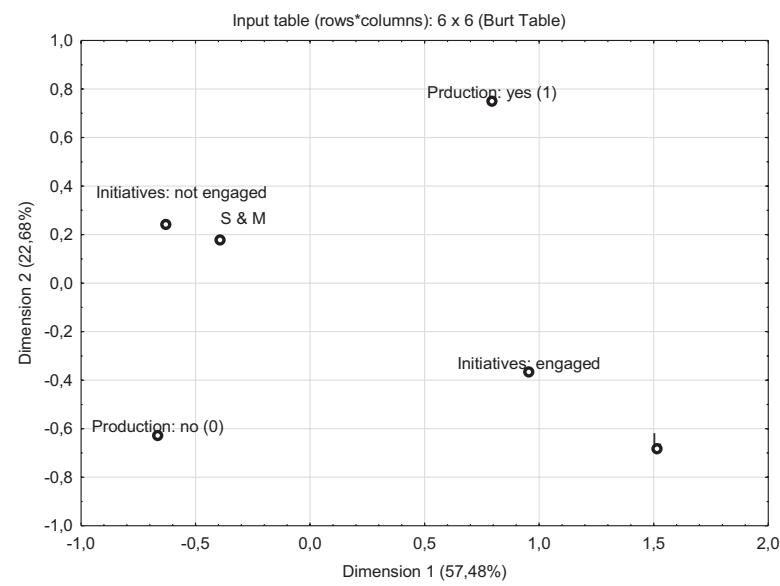

Figure 3. Correspondence analysis results

Source: Authors' own study.

Large (L) companies were involved in the implementation of pro-environmental activities more often than SMEs. Production entities were more involved in it, compared to non-production entities.

The results of the Mann-Whitney $U$ test and the chi-square independence test confirmed the research hypothesis. The involvement of companies in pro-environmental initiatives depends on the size of the company and the type of conducted activities. The availability of financial and human resources that a given entity may engage in pro-environmental activities depends mainly on the size of the company. On the other hand, even very small entities as well as those with limited financial resources can always find areas that need improvement in terms of their impact on the natural environment. 


\section{Discussion and conclusions}

The research showed that the scale and type of environmental initiatives implemented in companies are varied. This diversity is influenced by both the type of company activity and individual characteristics of companies, e.g. the size of the company. The production process is the production stage generating the most negative impacts on the natural environment. On the other hand, it is also the stage at which companies have the greatest possibility of operational control of their impact. In the area of production, the most important activities, closely related to the production processes, are waste management, gas emissions to the atmosphere, and hydro-sewage management. In the case of non-production companies, the most important environmental impacts are in the area of packaging waste management, energy consumption and fuel consumption in transport.

Despite the consent of both the environmental scientists and business practitioners regarding the significant impact of economic activity on the environment, there is still relatively low involvement of companies. There are at least two ways to explain it. Firstly, it can be considered that the companies investigated have already invested in environmental protection, that their operations are environmentally sound and that, in their view, no further improvements are necessary. Secondly, it is possible that the companies only comply with mandatory environmental requirements and do not want to invest in environmental protection because, for example, such activities bring them more costs than benefits. However, the study shows that the surveyed companies had doubts as to whether their environmental protection measures have contributed to the improvement of economic performance and an increase in the competitiveness of companies. More than specific economic benefits, companies expected to obtain image benefits. The improvement of the image may bring an increase in the competitiveness of companies, in which it requires a relatively longtime horizon and considerable financial outlays.

The presented results of the study are consistent with the results of other authors, alike, they both regard the impact of company characteristics on the degree of implementation of pro-environmental activities, as well as the scope of such activities. The results of the study may be useful at the planning stage of the environmental strategy of production companies, but also they can be a source of guidance for non-production entities, in particular at the stage of identifying the main impacts on the natural environment. On the other hand, the study highlights the need for further research on the effectiveness of voluntary activities of companies in the area of protection of the natural environment.

The presented study has its limitations. Its spatial scope, a relatively small research sample, and the way it is selected makes it difficult to generalize the results obtained. It should be noted, however, that these shortcomings relate to most of the preliminary studies, the purpose of which is not so much to develop general conclusions but to recognize the problem or test the hypothesis. 


\section{Acknowledgements}

This paper was prepared as a part of the research grant financed by the National Science Centre, Poland (grant no. 2016/23/D/HS4/03007).

\section{References}

Adamczyk, J. (2014). Obszary i kryteria oceny społecznej odpowiedzialności przedsiębiorstw. Prace Naukowe Uniwersytetu Ekonomicznego we Wrocławiu. Społeczna odpowiedzialność organizacji diagnoza i doskonalenie, 338.

Bugdol, M., Puciato, D., \& Borys, T. (2019). Development of tourism - barriers to shaping and recommendations for further research. Problems of Sustainable Development, 14(2).

Eryigit, N., \& Özcüre, G. (2015). Eco-innovation as modern era strategy of companies in developing countries: Comparison between Turkey and the European Union. Procedia - Social and Behavioral Science, 195. doi:10.1016/j.sbspro.2015.06.246

Hadryjańska, B. (2015). Ekologizacja procesu produkcji a ksztaltowanie konkurencyjności w przedsiębiorstwach przetwórstwa mleczarskiego. Poznań: Polskie Towarzystwo Ekonomiczne.

Jacobs, B.W., Singhal, V.R., \& Subramanian, R. (2010). An empirical investigation of environmental performance and the market value of the firm. Journal of Operation Management, 28(5). doi:10.1016/j.jom.2010.01.001

Koszarek-Cyra, A. (2016). Inicjatywy ekologiczne sektora MSP w państwach Grupy Wyszehradzkiej. Zeszyty Naukowe Politechniki Ślaskiej. Organizacja i Zarzązanie, 93.

Kożuch, M. (2012). Inwestycje ekologiczne a konkurencyjność przedsiębiorstw. Studia i Prace Wydziału Nauk Ekonomicznych i Zarzadzania, 25.

Liao, Z. (2018). Environmental policy instruments, environmental innovation and the reputation of enterprises. Journal of Cleaner Production, 171. doi:10.1016/j.jclepro.2017.10.126

Li, G., Wang, X., Su, S., \& Su, Y. (2019). How green technological innovation ability influences enterprise. Technology in Society, 59. doi:10.1016/j.techsoc.2019.04.012

O'Connor, J., \& Keil, M. (2017). The effects of construal level and small wins framing on an individual's commitment to an environmental initiative. Journal of Environmental Psychology, 52. doi:10.1016/j.jenvp.2017.04.010

Olejniczak, K. (2014). Reguła 3E jako podstawa zarządzania współczesnym przedsiębiorstwem. Studia Ekonomiczne, 180(2).

Paton, R.B. (2000). Voluntary environmental initiatives and sustainable industry. Business Strategy and the Environment, 9.

Sen, P., Roy, M., \& Pal, P. (2015). Exploring role of environmental proactivity in financial performance of manufacturing enterprises: A structural modelling approach. Journal of Cleaner Production, 108. doi:10.1016/j.jclepro.2015.05.076

Seroka-Stolka, O. (2017). Green initiatives in environmental management of logistics companies. Transportation Research Procedia, 16. doi:0.1016/j.trpro.2016.11.045

Urząd Marszałkowski Województwa Śląskiego (UMWŚ). (2009). Analiza skali zastosowania w MSP produktów i procesów przyjaznych dla środowiska oraz ich wplyw na środowisko naturalne województwa śląskiego. Raport końcowy. Katowice. Retrieved from https://efs.slaskie.pl/zalaczniki/2009/12/08/1260275397.pdf.

Wassmer, U., Cueto, D.C., \& Switzer, N. (2014). The effect of corporate environmental initiatives on firm value: evidence from Fortune 500 firms.M@n@gement, 14(1).doi:10.3917/mana.171.0001

Zutshi, A., \& Creed, A. (2015). An international review of environmental initiatives in the construction sector. Journal of Cleaner Production, 98. doi:10.1016/j.jclepro.2014.06.077 